Cell Research (2001); 11(3):165-180

http://www.cell-research.com

REVIEW

\title{
The angiotensin II type 1 receptor and receptor-associated proteins
}

\author{
GUO Deng Fu1, *, Yu lin SUn1, PaVel HAMET1, Tadashi INAGAMi2 \\ 1 Research Centre, Hotel-Dieu of CHUM and Department of Medicine, University of Montreal, Montreal, Quebec, \\ Canada H2W 1 T8 \\ 2 Department of Biochemistry, Vanderbilt University, School of Medicine, Nashville, TN, USA 37232-0146
}

\begin{abstract}
The mechanisms of regulation, activation and signal transduction of the angiotensin II (Ang II) type 1 (AT1) receptor have been studied extensively in the decade after its cloning. The AT1 receptor is a major component of the renin-angiotensin system (RAS). It mediates the classical biological actions of Ang II. Among the structures required for regulation and activation of the receptor, its carboxyl-terminal region plays crucial roles in receptor internalization, desensitization and phosphorylation. The mechanisms involved in heterotrimeric G-protein coupling to the receptor, activation of the downstream signaling pathway by $\mathrm{G}$ proteins and the Ang II signal transduction pathways leading to specific cellular responses are discussed. In addition, recent work on the identification and characterization of novel proteins associated with carboxyl-terminus of the AT1 receptor is presented. These novel proteins will advance our understanding of how the receptor is internalized and recycled as they provide molecular mechanisms for the activation and regulation of G-protein-coupled receptors.
\end{abstract}

Key words: RAS, Ang II, receptor, internalization, recycling, yeast two-hybrid system.

\section{INTRODUCTION}

The renin-angiotensin system (RAS) is considered to be the major regulator of blood pressure, electrolyte balance and renal, neuronal as well as endocrine functions related to cardiovascular control. The RAS is the key factor in most cases essential hypertension, as indicated by successes in treatment of hypertensive patients with various angiotensin I converting enzyme (ACE) inhibitors and receptor blockers. Renin was a central subject of intense investigation because of its role in blood pressure regulation before the discovery of angiotensinogen. Early studies by two groups, led respectively by Page and Braun-Menendez, independently demonstrated that renin was not the direct cause of experimental hypertension, but rather it acted on a substance in plasma to yield a heat-stable peptide possessing both

* Correspondence to: Deng Fu GUO, Ph.D., Tel: (514) 890-8000 ext. 14833 E-mail: guod@magellan.umontreal.ca pressor and vasoconstrictor functions[1], [2].

Renin is a protease and released from juxtaglomerular cells of the kidney. Angiotensinogen is a 56$60 \mathrm{kDa}$ glycoprotein produced mainly in the liver and released into the blood. It is the only known substrate for renin, and is cleaved at a position between 10 and 11 amino acids to generate angiotensin I (Ang I). Skeggs's group was the first to successfully purify Ang I and Ang II from horse plasma with large quantities of hog renin[3-5]. Subsequent studies by this same group characterized ACE, the enzyme which converts Ang I to Ang II[6]. Fig 1 shows the biochemical pathways of formation of active angiotensins from their prohormone, angiotensinogen. The biologically active form, Ang II, the effector molecule of this important biological system set, was instrumental in the effort to clone Ang II receptors.

Two distinct subtypes of Ang II receptors, AT1 and AT2, have been identified by using non-peptidic, 
subtype-selective antagonists (losartan for AT1 and PD123319 for AT2, respectively). Although both receptor types belong to the G-protein-coupled receptor superfamily which has seven transmembranespanning domains, the properties of the two Ang II receptors have been shown to be different. The AT1 receptors undergo rapid internalization and desensitization upon agonist stimulation, whereas AT2 receptors do not internalize and desensitize. This review focuses on regulation and activation of the AT1 receptor and receptor-associated proteins.

\section{Cloning of the AT1 receptor}

Numerous previous attempts to purify the AT1 receptor failed because of its instability and minute quantities present in various tissues. However, a new expression cloning technique resolved the problem of isolating AT1 receptor complementary DNA (cDNA) without purifying receptor proteins. In 1991, two groups adapted the expression cloning method, and successfully isolated full length cDNA of the AT1 receptor using the expression vectors pCDM8 and pCDNA1[7], [8]. Messenger RNAs from cultured bovine adrenal zona glomerulosa cells or rat aortic vascular smooth muscle cells (VSMC) were used to prepare a cDNA library, which was inserted into pCDM8 or pCDNA1 respectively, divided into small pools, then expressed and selected in Cos7 cells.

\section{Angiotensinogen}

$\mathrm{H}_{2} \mathrm{~N}$-Asp-Arg-Val-Tyr-Ile-His-Pro-Phe-His-Leu-Val-Ile-His-Asn-Glu-Protein

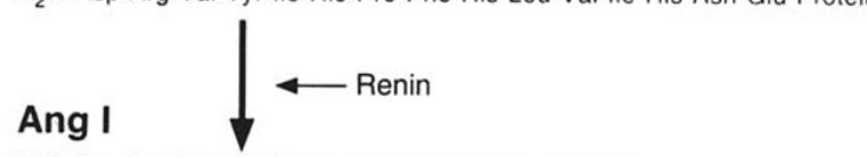

$\mathrm{H}_{2} \mathrm{~N}$-Asp-Arg-Val-Tyr-lle-His-Pro-Phe-His-Leu-COOH

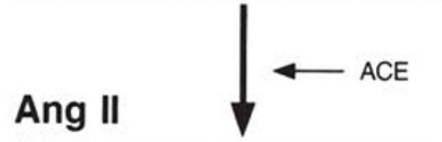

$\mathrm{H}_{2} \mathrm{~N}$-Asp-Arg-Val-Tyr-lle-His-Pro-Phe- $\mathrm{COOH}$

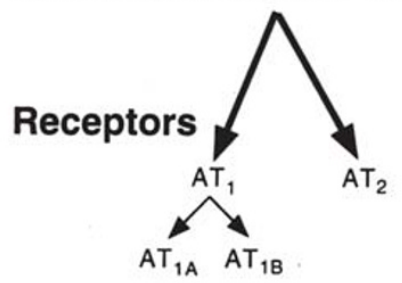

Fig 1. Pathways for the generation of biologically-active angiotensins from their prohormone angiotensinogen.
Cells transfected with plasmid containing cDNA for the receptor were identified by its binding to the radio-iodinated Ang II analog Sar1, Ile8-Ang II. The plasmid DNA of positive clones was re-isolated from the cells, transformed into bacteria competent cells, and amplified for secondary transfection. By repeating these steps, the final, single cDNA coding for the receptor was isolated. Sub-sequently, two different subtypes of the AT1 receptor, AT1A and AT1B, were identified in rodent animal, but not in mammalians including human by plaque hybridization screening[9-19].

Human AT1 was mapped on chromosome 3q213q25 by Curnow et al[20]. Rat AT1A was located on chromosome 17, and AT1B on chromosome 2[21], [22]. A non-mammalian high affinity receptor for Ang II was also found in Xenopus laevis cardiac membranes, characterized by binding- inhibition studies with peptide and non-peptide Ang II antagonists[23], and its cDNA was isolated[24]. Xenopus sp. myocardial Ang II receptor cDNA is 3,052 basepairs in length and contains an open reading frame of 1,086 base-pairs encoding a protein of 362 amino

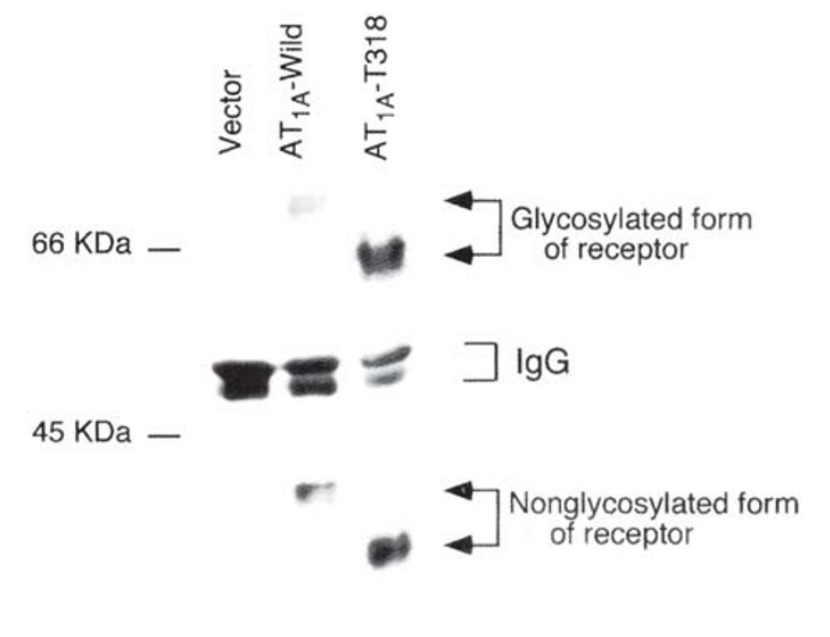

$31 \mathrm{kDa}-$

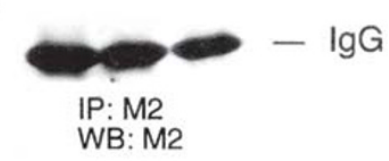

Fig 2. Western blot detection of immunoprecipitated Flag epitope-tagged AT1A and truncated mutant AT1A-T318 receptors in transiently transfected HEK-293 cells. 
acids. The Xenopus AT1 receptor has $58-60 \%$ amino acid identity and $65 \%$ nucleotide homology of the coding region with mammalian $\mathrm{AT} 1$ receptors and is pharmacologically distinct from them.

\section{Structure of the AT1 receptor}

The amino acid sequences encoded by the open reading frame of AT1 $\mathrm{cDNA}$ and genomic DNA of all mammalian and rodent species consist of 359 amino acid residues with a calculated molecular weight of $41 \mathrm{kDa}$, which is in agreement with that of the unglycosylated form of the AT1A receptor tagged with Flag epitope in transfected 293 cells (Fig 2). Structural predictions suggest an extracellular NH2-terminus followed by seven a-helical transmembrane-spanning domains, which are connected by three extracellular and three intracellular loops, linked to the carboxyl-terminus. Three consensus sites for $\mathrm{N}$-glycosylation can be found in Asn4 in the NH2-terminus and in Asn 176 and Asn 188 within the second extracellular loop. The carboxylterminal region is rich of serine, threonine and tyrosine residues, with three putative phosphorylation sites of protein kinase C (PKC) (Fig 3). Some of these residues are phosphorylated in an agonist-dependent manner and are predicted to play an important role in receptor internalization, desensitization and trafficking.

Hydropathy analysis of the amino acid sequence indicates that the AT1 receptor has seven a helical transmembrane domains characteristic of the superfamily of G-protein-coupled receptors, which is the biggest member of the human genome based on the findings of human genome projects. The amino acid sequence shows $20-35 \%$ homology with other G-protein-coupled receptors. Two pairs of disulfide bridges have been identified with four cysteine residues located in the extracellular domain. One of these bridges, spanning the second and third extracellular loops, is highly conserved in other G- proteincoupled receptors. The second disulfide bridge connects the $\mathrm{N}$-terminus and last extracellular loop. Disruption of this structure by interruption of the disulfide bridges could explain why the AT1 receptor is sensitive to sulfhydryl reagents such as dithiothreitol[27].

\section{Regulation of AT1 receptor gene ex- pression}

Studies on the genomic organization of rat AT1A and $\mathrm{AT} 1 \mathrm{~B}$, have revealed that rat $\mathrm{AT} 1 \mathrm{~A}$ has four exons, with the coding sequence located on the third exon[28], while rat AT1B has only three exons, with the coding sequence encoded in the third exon[29]. In contrast, human AT1 receptor gene consists of at least five exons, with the last exon containing the coding sequence[30]. The amino acid sequences encoded by the coding regions of AT1A and AT1B share 96\% homology, but there are marked differences in the non-coding regions, suggesting possible variations in the mechanism of receptor regulation. Although rodents have two AT1 receptor subtypes, AT1A and AT1B, which are expressed in different proportions in different tissues, their signaling mechanisms and binding to ligand are virtually identical, with the major difference residing in the manner of transcriptional regulation.

AT1A is dominant over AT1B in most cardiovascular tissues, while endocrine tissues such as the adrenal and pituitary glands express AT1B more than AT1A[12], [31]. Mice lacking the expression of these genes show that the AT1A receptor is far more important in the control of blood pressure. Systolic blood pressure is markedly reduced in mice that have no AT1A receptors while no significant difference of blood pressure is observed between wild type control animals and mice lacking the AT1B receptor gene[32-34]. Rat AT1A, AT1B and human AT1 5'-flanking region sequences have been determined. Sites for binding to the RNA polymerase II transcriptional complex, including the TATA box and possible GC box, have been found proximally upstream from the transcriptional start site(s). Functional responsive elements and suppressing/enhancing regions including glucocorticoid-responsive element and PEA3 factor binding site, have also been identified[35], [36].

Regulation of gene expression has been studied in rat mesangial and aortic smooth muscle cells in vitro. Makita et al[37] found that the treatment of mesangial cells with Ang II or forskolin markedly suppresses AT1A mRNA expression. These effects do not appear to be mediated by PKC or by a calmodulin-mediated signaling pathway. Studies have failed to identify transcriptional regulation, but the AT1A mRNA stabilization in its 3'-untranslated region may play an important role in down- regula- 
The angiotensin II type 1 receptor and receptor-associated proteins

tion of AT1A mRNA by Ang II (Uno S, Guo DF, Inagami $\mathrm{T}$, unpublished observation).

\section{Signaling transduction pathways of the AT1 receptor}

From studies focused on AT1 receptor-mediated signal transduction pathways, it has become apparent that Ang II-induced signal varies from seconds (e.g. activation of phospholipase C (PLC), generation of inositol phosphate and $\mathrm{Ca}^{2+}$ release) to minutes (e.g. mitogen-activated protein (MAP) kinase activation) to hours (e.g. activation of Janus kinase (JAK) and signal transducers and activators of transcription (STAT) pathway) after Ang II stimulation (Fig 4).

The signal transduction pathway of the AT1 receptor is mediated by $\mathrm{Gq} / 11$-proteins activating the $\mathrm{Ca}^{2+}$ signal and the PKC-mediated system. The effects of Gq-protein-mediated activation of the AT1 receptor varies in different tissues, including vasoconstriction, aldosterone release, renal sodium reabsorption, adrenergic facilitation, VSMC hypertrophy and cardiac myocyte hyperplasia. In VSMC, Ang II activates numerous tyrosine phosphorylated proteins, which share similarity with that the response to growth factors and cytokines, including the JAK kinase family, JAK2 and Tyk2[38], [39], the Src kinase family, Fyn and c-Src[40], [41], the growth factor receptor family, platelet-derived growth factor receptor (PDGFR), epidermal growth factor receptor (EGFR) and insulin growth factor receptor (IGFR)[42-46], the STAT transcriptional factor family[47], [48], and the cell adhesion proteins, Paxillin and focal adhesion kinase (FAK) [49], [50]. In addition, the adaptor protein SHC, tyrosine phosphatase SHP2, PLC- $\gamma 1$, p130CAS and insulin receptor substance 1 (IRS1) are also tyrosinephosphorylated in response to Ang II[42], [51-53].

Another important signal transduction pathway induced by Ang II is the PKC signaling pathway. PKCs are serine/threonine kinases whose substrates include proteins that are important in cellular proliferation. There are currently 11 members belonging to the PKC family that could be divided into three subtypes according to their mechanisms of activation. The activation of phospholipases through both G-protein-dependent and G-protein-independent mechanisms causes PIP2 to be hydrolyzed to two important molecules, IP3 and diacylglycerol (DAG). DAG, in turn activates PKC. The carboxylterminal region of the AT1 receptor has been shown to be phosphorylated by PKC, indicating that AT1 receptor activation is $\mathrm{PKC}$-dependent[54]. The role of PKC in Ang II signaling has been studied by down-regulating PKC activity through prolonged exposure to phorbol esters or activation of PKC by short time exposure to phorbol esters in cultured VSMC. Down regulation of PKC significantly reduces Ang II-mediated induction of expression of early response genes as well as cellular proliferation [55], [56]. Thus, it is likely that events such as smooth muscle cell proliferation, seen in some vascular diseases, willhave a PKC-dependent component.

G-protein activation by the AT1 receptor initiated a search for the region of the AT1 receptor that mediates this activation. Coupling to heterotrimeric G-proteins is dependent upon the proximal region of the carboxyl-terminus of AT1 receptor specifically, the hydrophobic cluster of Tyr312, Phe313 and Leu314[57], [58]. Site-directed mutagenesis studies have revealed that Tyr312, Phe313 and Leu314 yield receptors that are insensitive to GTPgS and display a reduced capacity to liberate IP3 formation after Ang II stimulation, indicating uncoupling from G-proteins in transfected mammalian cells. Also, purified peptides containing the wild type sequence but not mutations at Tyr312, Phe313 and Leu314 are able to activate GTP $\gamma \mathrm{S}$ binding to purified Gproteins.

Interestingly, the carboxyl-terminus of AT1 receptor also interacts with proteins other than $\mathrm{G}$ proteins. After the initial report of induction of the JAK-STAT pathway by the AT1 receptor, Marrero et al [38] demonstrated that it interacts directly with JAK2 kinase, providing the mechanism of JAKSTAT activation. Subsequently, they proposed that JAK2 is associated with the AT1A receptor through the Tyr319Ile320Pro321Pro322 (YIPP, Fig 3) sequence within the proximal carboxyl-terminal region of AT1A receptor[59]. While this YIPP motif may function as a SH2 targeting sequence upon phosphorylation of Tyr319, JAK2 contains no SH2 domains that could putatively mediate the association. Moreover, Oppermann et al[60] found little evidence of tyrosine phosphorylation of the AT1 receptor, al- 
though Venema et al[61] recently reported robust tyrosine phosphorylation of the AT1A receptor in VSMC after Ang II treatment. The controversy in data interpretation using current AT1 receptor antibodies[61] versus epitope-tagged receptors[60], [61] warrants that further studies to resolve the issue of whether the AT1 receptor becomes tyrosine phosphorylated, especially on Tyr319, after Ang II stimulation. Phospho amino acid analysis using immunoprecipitated epitope-tagged receptor will help to resolve this issue in future investigation. Nevertheless, lack of the SH2 domain of JAK2 kinase leads to the prediction that adaptor proteins may be the link between JAK2 and the YIPP motif of the AT1 receptor. The SH2 domain containing SHP-2 phosphotryosine phosphatase has been identified as the possible adaptor molecule[61].

The pathway was also found by using EGFR, which provides a scaffold for the activation of MAP kinase cascades[44-46]. EGFR was tyrosine-phosphorylated by unknown tyrosine kinases, but it was clearly demonstrated that EGFR activity was not activated by Ang II stimulation. The pathway that the AT1 receptor stimulates tyrosine phosphorylation of EGFR is not known. A $\mathrm{Ca}^{2+}$-dependent tyrosine kinase, Pyk2 may be involved in EGFR activation, or the C-Src family of tyrosine kinase may

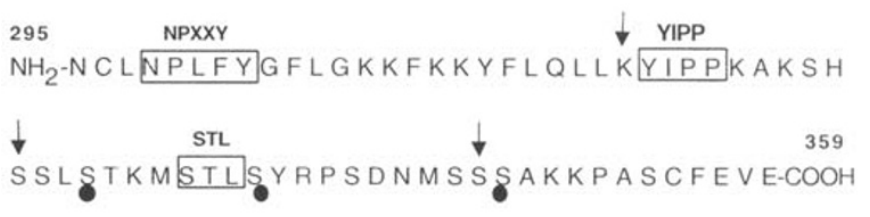

Fig 3. Schematic representation of the carboxyl-terminus of the rat AT1A receptor There are four putative tyrosine residues and three putative PKC sites. The black dots indicate putative PKC sites. The NPXXY, STL and YIPP motifs are shown in open boxes. The three truncated deletion mutants created in our laboratory are identified by arrows. The STL motif has been shown important for receptor internalization. The YIPP motif has been reported to interact with JAK2 tyrosine kinase.

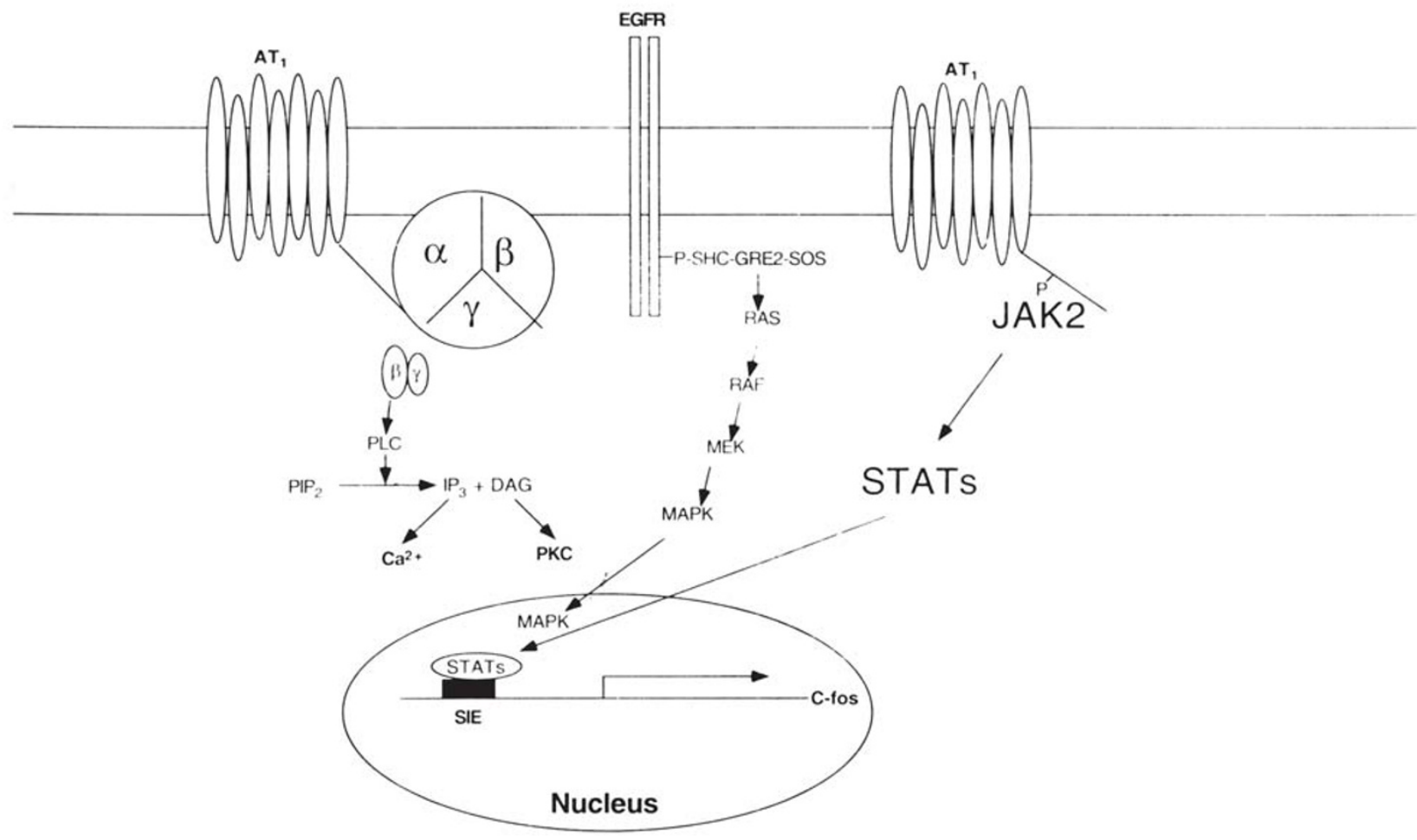

Cellular response: constriction, migration, growth and hypertrophy

Fig 4. Illustration of angiotensin II signal transduction pathways involving heterotrimeric G-proteins and tyrosine kinase cascades. 
be implicated in this pathway, which is still hypothetical and requires further investigation. Nonetheless, the general direction of AT1 receptor is that of a positive activator of protein tyrosine phosphorylation, which plays a pivotal role in immediate, early gene expression leading to cell proliferation and hypertrophy. Fig 4 outlines the features of G-protein, MAP kinase and JAK-STAT signaling that arediscussed in this review. Cellular responses are also depicted in the figure.

\section{Functional domains of the AT1 receptor}

Elucidation of the mechanism of action of the AT1 receptor requires identification of the Ang II binding sites, structures involved in the ensuing conformational changes of the receptor and in interaction with G-proteins. Furthermore, the structural features of regulation by internalization, desensitization and phosphorylation have been examined extensively. These objectives have been approached by site-directed mutagenesis with biochemistry and pharmacological experiments. These studies have revealed that the carboxyl-terminus of the AT1 receptor plays pivotal role on receptor internalization, desensitization, phosphorylation, coupling to G-proteins and other proteins except binding to Ang II (Fig 3).

The peptide Ang II should bind over a sizeable binding domain. Based on a number of pharmacological, mutagenesis and computer-oriented modeling studies[63-76], the general agreement is that a positively-charged residue of Lys199 on transmembrane domain (TM)-5 of the AT1 receptor interacts with the $a$-carboxyl group of Phe8 in Ang II. This interaction is crucial for high affinity binding of Ang II to the receptor. In addition to this coupling, interactions between His183 in the second extracellular loop and Asp1 in Ang II, and Asp281 in TM-7 with Arg2 in Ang II stabilize the receptor and Ang II binding. Moreover, the interactions of His256, Val254 and Phe259 in TM-6 with the aromatic sidechain of Phe8 in Ang II and Asn111 in TM-3 with Tyr4 in Ang II have been postulated to contribute to Ang II docking with the receptor.

\section{Receptor internalization}

Growth factor receptors with intrinsic tyrosine kinase activity and G-protein-coupled receptors are internalized by a similar clathrin-coated vesicular endocytic process[77]. The coat of clathrin-coated vesicles consists of a complex of clathrin and clathrin adaptor proteins. Of the two types of clathrin- coated vesicles, one mediates internalization of the receptor-ligand complex from the plasma membrane, and the other transports newly-synthesized proteins from the trans-Golgi network. The plasma membrane and Golgi complex-associated clathrin-coated vesicles contain different adaptor complexes, referred to as HA2 (AP2) and HA1 (AP1), respectively[78], [79]. Clathrin plays a mechanical role in vesicle budding, while the adaptor proteins AP1 and AP2 are thought to link clathrin to the cytoplasmic domains of a select group of Golgi proteins or plasma membrane proteins such as receptors[78]. High-resolution electron microscopy suggests that the coat consists of an outer lattice of clathrin and an inner shell that contains brick-shaped adaptor complexes. The adaptor complexes thus lie immediately adjacent to the cytoplasmic face of the plasma membrane and are able to interact directly with the carboxyl terminus of the receptors. This notion was first verified for EGFR, showing that AP2 interacts directly with the carboxyl terminus of the receptors[78].

Internalization motifs identified within the carboxyl-terminal region of the AT1 receptor supposedly mediate the recruitment of activated receptors into well-known clathrin-coated pits and vesicles. These motifs are presumed to bind adaptor protein complexes, such as AP2, which interact with the clathrin lattice to promote internalization and form vesicles. Extensive mutagenesis studies of the AT1 receptor, aimed at identifying endocytotic motifs, have revealed two separate domains of the carboxylterminus and one in the third intracellular loop that are important for receptor internalization [54],[64], [80-86]. These truncated receptors display a high affinity for Ang II, signaled in response to Ang II stimulation, demonstrating that other receptor functions are not affected. An amino acid triplet, Ser335Thr336Leu337 (Fig 3), has been shown to contribute to AT1 receptor endocytosis. Additional studies by Thomas's group found that the STL motif is essential for receptor internalization, but requires one more closer region between amino acids 315 and 329 for maximal receptor internalization[82]. In particular, two of the mutants (Leu316Phe and Tyr319Ala) within the region display significantly 
reduced internalization rates.

\section{Receptor desensitization}

Signal transduction by G-protein-coupled receptors is often accompanied by rapid desensitization, i.e. attenuation of the cellular response upon prolonged or repeated agonist exposure. Extensive studies of $\beta 2$-adrenergic receptors have revealed the existence of three major mechanisms of receptor desensitization: 1) rapid uncoupling from G-protein, 2 ) sequestration of receptors into endosomal vesicles, and 3) downregulation of the total number of receptors[87-89]. Rapid uncoupling of the ligand-receptor complex from G-protein occurs in a very short time (seconds to minutes after ligand binding) and shifts the receptor to a low-affinity form. Heterologous desensitization of the $\beta 2$-adrenergic receptor requires the phosphorylation, by protein kinase $\mathrm{A}$ (PKA), of two serine residues located in the third cytoplasmic loop and in the proximal portion of the carboxyl terminus, whereas agonist-induced homologous desensitization of the receptor requires phosphorylation of clustered serine/threonine residues in the distal portion of the carboxyl terminus by $\beta 2$ adrenergic receptor kinases (GRKs). Phosphorylation of the cytoplasmic tail by GRKs favors binding of arrestin-like proteins to the receptor, which blocks its physical coupling to Gs-protein and adenylyl cyclase[90, 91]. Sequestration and downregulation involve the internalization of receptors in different types of vesicles and specific sorting mechanisms to recognize and deliver internalized receptors to either the recycling or degradation (lysosome) pathway. It should be noted that sequestration does not appear to play a major role in desensitization but may instead be involved in the resensitization process [92].

The serine- and threonine-rich carboxyl-terminal region of the AT1 receptor is thought to be phosphorylated and to play a key role in the desensitization of AT1 responses. Desensitization is characterizated by a reduction in magnitude of signaling in response to repeated and prolonged stimulation by ligands. Our studies have shown that the region between 329 and 347 within the carboxylterminus is critical for Ang II- and phorbol esterinduced desensitization by using three truncation of the receptors at positions 318, 328 and 347 (see
Fig 3)[54]. In addition, Conchon et al[93] have reported the activation and desensitization of the AT1 receptor by using six mutants truncated at positions 303, 313, 328, 335, 340 and 346 within the carboxyl-terminus. Truncation of the receptor after position 328 displays an amplification of the Ang IIinduced intracellular signal as a consequence of reduced desensitization. Low desensitization to phorbol ester, observed with the wild type receptor, is also abolished in these mutant receptors. Receptor truncated after position 340 are indistinguishable from wild type receptors, confirm our findings that the region between 328 to 340 is important for receptor desensitization. A role for $\mathrm{PKC}$ in receptor desensitization may be required for low-dose (1 nM range) Ang II or heterologous stimulation. A recent study by Feng et al.[94] supported heterologous AT1 receptor desensitization following stimulation of the endothelin A receptor, presumably as a result of PKC activation and translocation to the plasma membrane.

\section{Receptor dimerization}

For many growth factor and cytokine receptors, the principal mechanism initiating receptor-mediated signaling is ligand-dependent receptor autotyrosine phosphorylation and dimerization. The phosphorylated receptor recruits additional signaling molecules to the dimer. As a result, intracellular signaling cascades and growth factor and cytokine responses are initiated. An intriguing possibility, based on exciting preliminary data from other Gprotein-coupled receptors, is that AT1 receptors may undergo agonist-induced dimerization, and that this process is involved in modulating receptor internalization. Recent studies on other G-proteincoupled receptors have been observed that $\beta 2$ adrenergic, muscarinic, dopamine D2 and opioid receptors undergo dimerization following agonist stimulation[95-100]. Receptor dimerization is likely initiative step toward receptor internalization following agonist stimulation. However, its role in receptor signal transduction pathways is not understood. Using different epitope tags to the AT1A receptor, our preliminary results indicate that it also undergoes dimerization, and its carboxyl-terminus seems to be involved in this process. Detailed mechanisms of receptor dimerization and its impor- 
The angiotensin II type 1 receptor and receptor-associated proteins

tance in receptor activation still require for further investigation.

\section{Receptor phosphorylation}

Unlike many growth factor and cytokine receptors, the AT1 receptor lacks intrinsic kinase domains in intracellular loops and in the carboxyl-terminus. The ability of anti-AT1 receptor antibodies to detect the receptor by Western blotting and to collect the receptor by immunoprecipitation has been one of the major controversies in this field of research. Most of research groups including us have attempted, but failed to raise specific antibodies against AT1 receptor. However, several groups have reported the AT1 receptor phosphorylation[60, 62, 101-105]. Among these, Smith et al[102] produced polyclonal antibodies against a fusion protein containing carboxyl-terminus of the AT1B receptor. They provided compelling evidence that these antibodies have the ability to detect and immunoprecipitate the endogenous AT1 receptor from bovine adrenal glomerullar cells. Moreover, they demonstrated that AT1 receptor phosphorylation is Ang II-dependent.

Controversies and difficulties in raising anti-AT1 receptor antibodies led many groups to explore alternative ways of overcoming this problem. Epitopetagged receptors with subsequent detection and immunoprecipitation of tagged peptides with commercially-available and well-characterized monoclonal antibodies are widely used for protein detection, intracellular localization and protein-protein interaction. The AT1A receptor with HA (influenza hemagglutinin antigen) epitope at the $\mathrm{N}$-terminus was first created and transiently transfected in HEK293 cells. A broad band of 60-150 kDa was observed by sodium dodecyl sulphate-polyacrylamide gel electrophoresis (SDS-PAGE). Oppermann et al[60] demonstrated that the HA-tagged AT1A receptor was phosphorylated in an agonist-dependent manner. They also showed that the HA-tagged AT1A receptor was phosphorylated by G-protein-coupled receptor kinases 2 and 5 and PKC. Balmforth et al[101] generated hexahistidine-tagged AT1A receptor which the receptor could be purified with $\mathrm{Ni} 2+$ beads and detected with anti-His antibodies. They demonstrated that the His-tagged AT1A receptor was phosphorylated following Ang II stimulation. Moreover, they showed the receptor complex with
125I-labelled Sar1Ile8-Ang II. Thomas et al[62] further identified the regions and residues phosphorylated on the receptor, using a series of truncated HA-tagged AT1A receptors. They suggested that the region between 326 to 359 of the receptor was involved in Ang II-induced receptor phosphorylation.

Despite efforts to raise antibodies against the AT1 receptor or to use epitope-tagged AT1 receptor, none of these studies clearly reported receptor detection and immunoprecipitation . In our laboratory, we created the modified Flag-epitope tagged AT1A receptor, which contains the prolactin signal sequence followed by the Flag epitope sequence and then by the AT1A receptor sequence. Using commercially-available anti-Flag antibodies, we clearly demonstrated that wild type as well as truncated Flag-tagged AT1 receptors were immunoprecipitaed and detected with monoclonal anti-Flag antibodies by Western blotting (see Fig 2). Glycosylated and unglycosylated receptor forms were found. The glycosylated form of the wild type AT1A and truncated mutant AT1A-T318 receptor migrated at 70 and $66 \mathrm{kDa}$ respectively, in 10\% SDS-PAGE, while the unglycosylated form migrated at 41 and $36 \mathrm{kDa}$, respectively. Moreover, we also created the Myc epitope-tagged AT1A receptor, which enbled us to determine receptor dimerization.

\section{Receptor trafficking}

At present, little is known about the mechanisms regulating intracellular trafficking of the AT1 receptor. However, using confocal laser scanning microscopy Hein et al[106] demonstrated that the complex of FITC-coupled Ang II and Flag epitope tagged-AT1A receptor was internalized into endosomes. After removal of Ang II, the AT1 receptor was recycled back to the plasma membrane, while Ang II was targeted to the lysosomal degradation pathway. Future studies using green fluorescenece protein (GFP) fusion with the AT1 receptor and real time laser scanning microscopy may provide detailed evidence of receptor intracellular trafficking.

\section{Identification of AT1 receptor-associated proteins}

As mentioned above, the carboxyl-terminus of the AT1 receptor has been demonstrated to associate with at least two proteins, heterotrimeric Gprotein, Gq/11 and JAK2 tyrosine kinase. Methods 
have been adapted to identify proteins interacting with the carboxyl-terminal region of the AT1 receptor in order to clarify the molecular mechanisms of receptor endocytosis and recycling. Employing yeast two-hybrid screening of a mouse kidney cDNA library with the carboxyl-terminal cytoplasmic domain of the murine AT1A receptor (amino acids 297 to 359) as bait, Dzau' s group[107] isolated a novel
HumanARAP1
Rat ARAP1
Mouse ARAP1
Consensus
MRPLCVTCWW LGLLAAMGAV AGQEDGFEGT EEGSPREFIY LNRYKRAGES MRPLCMTYWW LGLLATVGAV TGPEADVEGA EDGSQREYIY LNRYKRAGES MRPLCMTYWW LGLLATVGAA TGPEADVEGT EDSSQREYIY LNRYKRAGES MRPLC.T.WW LGLLA..GA. .G.E...EG. E..S.RE.IY LNRYKRAGES

\section{$\longrightarrow$ Coiled-coil domain}

QDKCTYTFIV PQQRVTGAIC ANSKEPEVLL ENRVHKQELE LLNNELLKQK PDKCTYTFIV PQQRVTGAIC VNSKEPEVHL ENRVHKQELE LLNNELLKQK PDKCTYTFIV PQQRVTGAIC VNSKEPEVHL ENRVHKQELE LLNNELLKQK .DKCTYTFIV PQQRVTGAIC .NSKEPEV.L ENRVHKQELE LLNNELLKQK Coiled-coil domain

RQIETLQQLV EVDGGIVSEV KLLRKESRNM NSRVTQLYMQ LLHEIIRKRD RQIETLQQLV EVDGGIVSEV KLVRKESRNM NSRVTQLYMQ LLHEIIRKRD RQIETLQQLV EVDGGIVSEV KLLRKESRNM NSRVTQLYMQ LLHEIIRKRD RQIETLQQLV EVDGGIVSEV KL.RKESRNM NSRVTQLYMQ LLHEIIRKRD

\section{Coiled-coil domain}

NALELSQLEN RILNQTADML QLASKYKDLE HKFQHLATLA HNQSEIIAQL NALELSQLEN RILNQTADML QLVSKYKDLE HKFQHLDMLA HNQSEVIAQL NALELSQLEN RILNQTADML QLASKYKDLE HKFQHLAMLA HNQSEVIAQL NALELSQLEN RILNQTADML QL.SKYKDLE HKFQHL..LA HNQSE. IAQL Coiled-coil domain

EEHCQRVPSA RPVPQPPPAA PPRVYQPPTY NRIINQISTN EIQSDQNLKV EEHCQRVPAA RPVPQPPPAT PPRVYQPPTY NRIINQISTN EIQSDQNLKV EEHCQRVPAA RPMPQPPPAA PPRVYQPPTY NRIINQISTN EIQSDQNLKV EEHCQRVP.A RPVPQPPPA. PPRVYQPPTY NRIINQISTN EIQSDQNLKV

$\longrightarrow$ Fibrinogen-like domain

LPPPLPTMPT LTSLPSSTDK PSGPWRDCLQ ALEDGHDTSS IYLVKPDNTN LPPSLPTMPA LTSLPSSTDK PSGPWRDCLQ ALEDGHSTSS IYLVKPENTN LPPSLPTMPA LTSLPSSTDK PSGPWRDCLQ ALEDGHSTSS IYLVKPENTN LPP.LPTMP. LTSLPSSTDK PSGPWRDCLQ ALEDGH.TSS IYLVKP.NTN

Fibrinogen-like domain

RLMQVWCDQR HDPGGWTVIQ RRLDGSVNFF RNWETYKQGF GNIDGEYWLG RLMQVWCDQR HDPGGWTVIQ RRLDGSVNFF RNWETYKQGF GNIDGEYWLG RLMQVWCDQR HDPGGWTVIQ RRLDGSVNFF RNWETYKQGF GNIDGEYWLG RLMQVWCDQR HDPGGWTVIQ RRLDGSVNFF RNWETYKQGF GNIDGEYWLG

Fibrinogen-like domain

LENIYWLTNQ GNYKLLVTME DWSGRKVFAE YASFRLEPES EYYKLRLGRY LENIYWLTNQ GNYKLLVTME DWSGRKVFAE YASFRLEPES EYYKLRLGRY LENIYWLTNQ GNYKLLVTME DWSGRKVFAE YASFRLEPES EYYKLRLGRY LENIYWLTNQ GNYKLLVTME DWSGRKVFAE YASFRLEPES EYYKLRLGRY

Fibrinogen-like domain

HGNAGVSFTW HNGRQFTTLD RDHDVYTGNC AHYQKGGWWY NACAHSNLNG HGNAGDSFTW HNGKQFTTLD RDHDVYTGNC AHYQKGGWWY NACAHSNLNG HGNAGDSFTW HNGKQFTTLD RDHDVYTGNC AHYQKGGWWY NACAHSNLNG HGNAG.SFTW HNG.QFTTLD RDHDVYTGNC AHYQKGGWWY NACAHSNLNG

VWYREGHYRS RYQDGVYWAE FRGGSYSLKK VVMMIRPNPN TFH VWYRGGHYRS RYQDGVYWAE FRGGSYSLKK VVMMIRPNPN TFH VWYRGGHYRS RYQDGVYWAE FRGGSYSLKK VVMMIRPNPD IFH VWYR.GHYRS RYQDGVYWAE FRGGSYSLKK VVMMIRPNP. .FH
50

100

150

200

250

300

350

Fig 5. Comparison of the amino acid sequence of human, rat and mouse ARAP1. Arrows show the region of coiled-coil and fibrinogen-like domains. 
protein, termed AT1 receptor-associated protein (ATRAP). ATRAP is a relatively small protein, encoding an open reading frame of 161 amino acids with a predicted molecular mass of $18 \mathrm{kDa}$. It has one potential $\mathrm{N}$-glycosylation site, one potential PKC phosphorylation site, and one casein kinase II phosphorylation site. Its NH2-terminus contains extensive hydrophobic residues. ATRAP mRNA is expressed at a relatively high level in the kidney, heart and testis, but at a lower level in the lung, liver, spleen and brain. In vitro interaction between the AT1 receptor and ATRAP has been demonstrated using the carboxyl-terminus fused with maltose-binding protein and HA epitope-tagged-ATRAP expressed in -transfected Cos 7 cells. ATRAP interacts specifically with the carboxyl-terminus of the AT1 receptor but not with those of the AT2 receptor. Moreover, binding of the Flag epitope-tagged AT1A receptor and HA epitope-tagged ATRAP was confirmed by co-immunoprecipitation from transfected Cos 7 cells. In addition, co-localization of the AT1 receptor and ATRAP was examined in Cos 7 cells co-transfected with HA epitope-tagged ATRAP and Flag epitope-tagged AT1A receptor. Two proteins are co-stained and located at the periphery of the cells and in intracellular compartments.

Using a truncated mutant receptor, the region between 339 to 359 within the carboxyl-terminus of the AT1A receptor was identified as the ATRAPbinding site. Receptor desensitization affected by ATRAP was examined with agonist-dependent PLC activation. PLC activity was markedly inhibited by an average of $35 \%$ in cells co-transfected with ATRAP and AT1 receptors when compared with cells co- transfected with AT1A receptor and vector plasmid, indicating that ATRAP overexpression regulates AT1 receptor desensitization. No effect of ATRAP overexpression was observed on m3 muscarinic receptor-mediated PLC activation. No interaction between ATRAP and the carboxyl-terminus of numerous Gq/Gs-coupled receptors, m3 muscarinic, bradykinin B2, endothelin B and b2adrenergi receptors was obtained by yeast two-hybrid assay, suggesting that ATRAP is specifically associated with the AT1 receptor. Further studies by the same group[108] demonstrated that ATRAP overexpression enhances AT1 receptor internalization in VSMC, indicating that ATRAP affects not only receptor desensitization, but also receptor internalization. Moreover, they found that ATRAP overexpression inhibits cell growth as measured DNA synthesis in VSMC. This inhibition may be caused at least partially, by reduction of protein tyrosine phosphorylation such as STAT3 and AKT and MAP kinases which have been reported to play pivotal roles in AT1 receptor-mediated cell growth in VSMC.

In our laboratory, we employed same yeast twohybrid screening approach with amino acid residues from 295 to 359 within the carboxyl-terminus of the rat AT1A receptor as bait. A novel protein, termed ARAP1 (Ang II type 1 receptor associated protein), was isolated with a mouse 10.5-day embryo cDNA library. A full length, 2,138 base-pair rat ARAP1 cDNA clone contained an open reading frame of 1 , 479 base-pairs encoding a hydrophilic protein of 493 amino acid residues with a calculated molecular mass of 57,156 Da. Rat ARAP1 shares $95 \%$ of amino acid homology with human and mouse (Fig 5). An amino acid sequence database search revealed a region of $20 \%$ identity over a 108 amino acid residue stretch between ARAP1 (residues 95 to 202) and yeast PEP12, without any gaps. The yeast PEP12 protein was localized in the pre-vacuolar endosome and its activity is required for transporting proteins from the Golgi to the vacuoles[109], [110]. This suggests the possible role of ARAP1 in intracellular traffick-

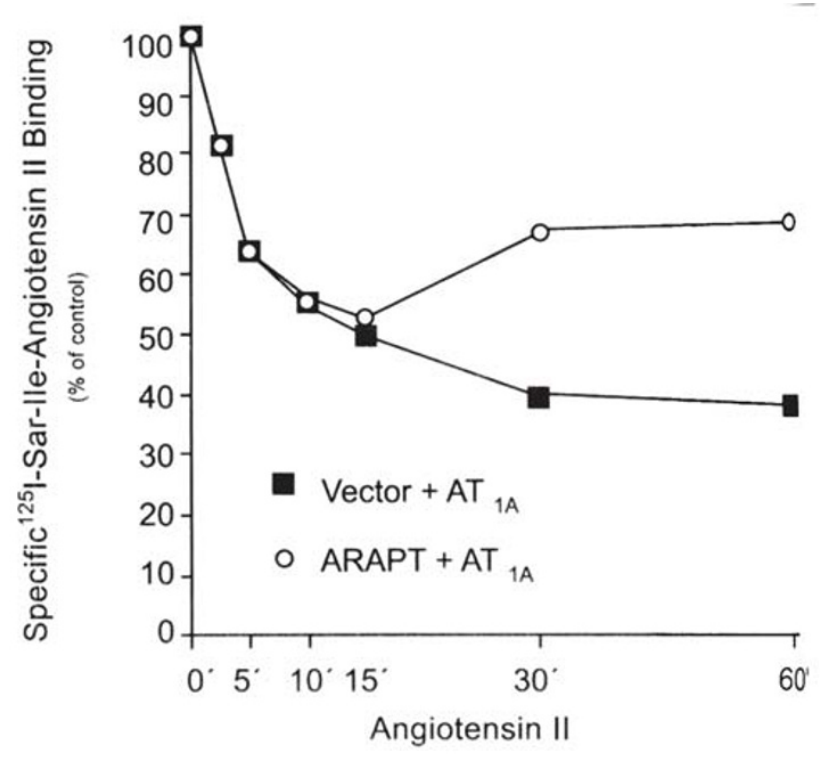

Fig 6. Kinetics of internalization of the AT1A receptor in the presence or absence of ARAP1. 
ing of the AT1 receptor. A region of $43 \%$ identity over 216 amino acid residues between ARAP1 (residues 272 to 487 ) and fibrinogen was also identified by database searches with three gaps of 23 residues. Moreover, a coiled-coil domain in the NH2terminus was found in ARAP1, indicating potential protein-protein interaction. ARAP1 mRNA was expressed in most rat tissues at a high level in the heart and kidney, but at a lower level in the brain, lung, liver, and testis. A truncated mutant of the AT1A318 receptor was found to be unable to interact with ARAP1 in yeast two-hybrid assay, indicating that the region between 319 to 359 within the carboxylterminus of the AT1 receptor is the binding site for ARAP1. This interaction was further confirmed in vitro, using HEK-293 cells transfected with Flag epitope-tagged AT1A-T318 (truncated receptor) and Myc epitope-tagged ARAP1. A complex of Myc
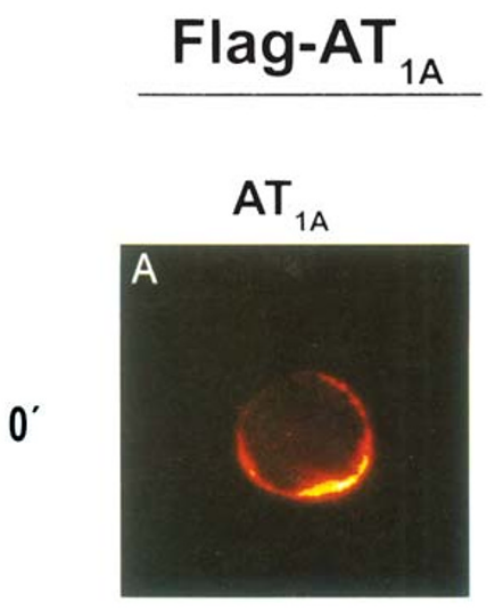

$15^{\prime}$

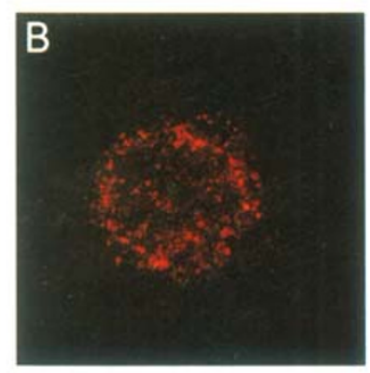

$45^{\circ}$

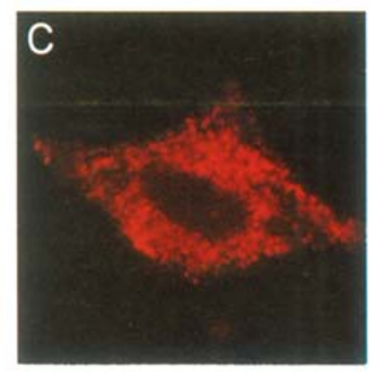

\section{Flag-AT $_{1 \mathrm{~A}}+$ GFP-ARAP1}
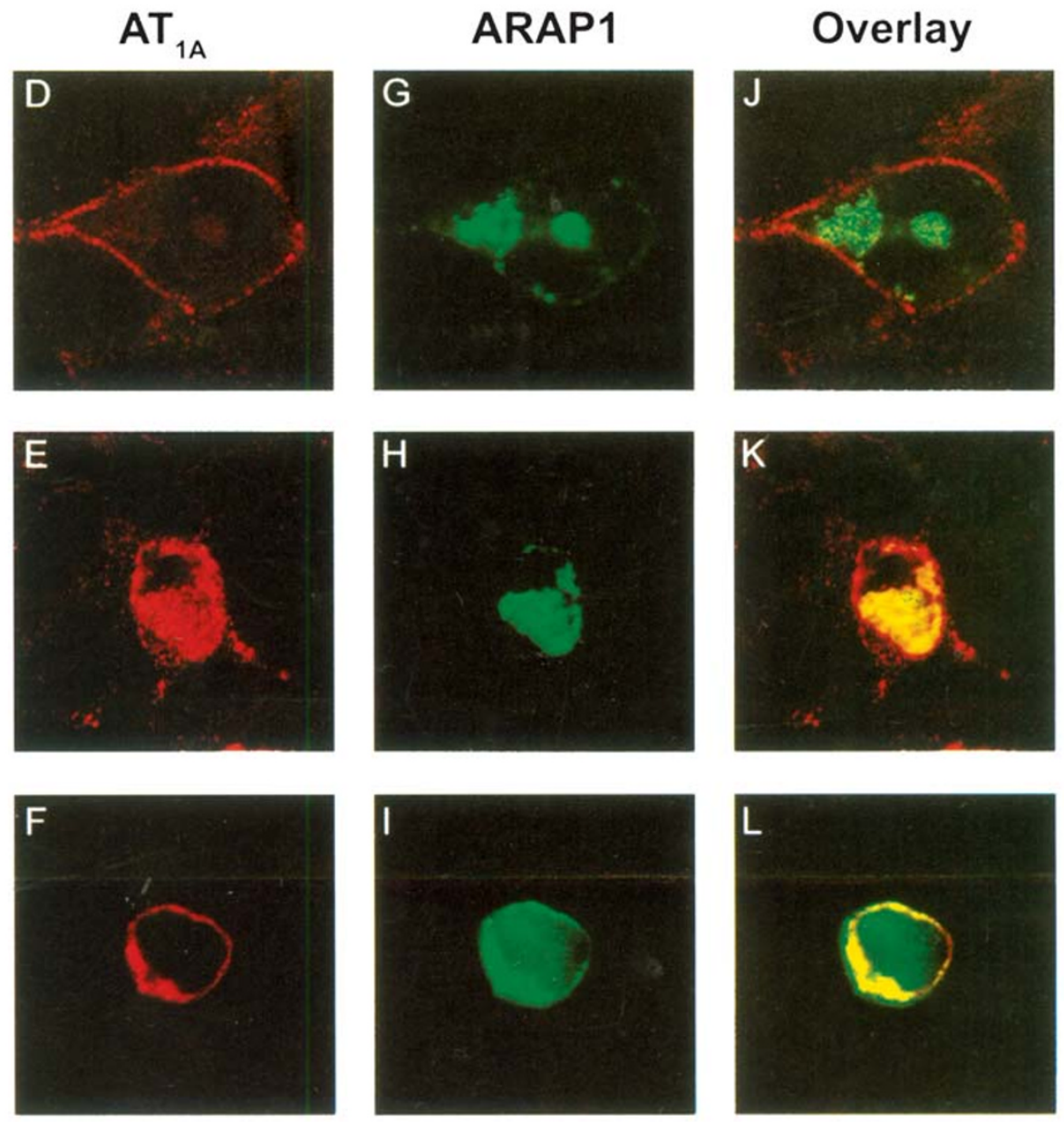

Fig 7. Imaging of AT1A receptor recycling by ARAP1 HEK-293 cells were transfected with GFP-ARAP1 (D-L) or not (A-C) and processed for immunocytochemical analysis of the distribution of the Flag epitope-tagged AT1A receptor. Each panel shows a single confocal section with green color indicating GFP-ARAP1, and red color, the AT1A receptor. Note that the receptor is localized at the plasma membrane (A, D) in unstimulated HEK-293 cells. At 15 min after Ang II addition, most of the receptor is in the cytosol in either the absence (B) or presence (E) of GFP-ARAP1. However, whereas in the absence of GFPARAP1, the receptor is largely in the cytosol at 45 min after Ang II stimulation, in cells expressing ARAP1 it is mostly in the cytoplasmic membrane. A similar distribution is observed for GFP-ARAP1 (G-I). At 45 min after Ang II stimulation, the two proteins show partial co-localization as indicated by yellow color. Bar $=10 \mu \mathrm{m}$. 
epitope-tagged ARAP1 and Flag epitope-tagged AT1A was observed by co- immunoprecipitation and Western blotting in transfected HEK-293 cells.

To determine whether rat ARAP1 regulates AT1 receptor expression, a radioligand binding assay was performed in HEK-293 cells co-transfected transiently with the vector or rat ARAP1 with rat AT1A receptor (Fig 6). Without transfection of rat ARAP1, AT1A was rapidly internalized and reached a minimal level (40\% of the original) at 30 min following exposure of the cells to $100 \mathrm{nM}$ Ang II. No further decrease of receptor number on the cell surface was detected. A marked increase of receptor number in cell surface was observed in cells transfected with ARAP1 at 30 min post-exposure of the cells to 100 $\mathrm{nM}$ Ang II, although AT1 receptor internalization was not affected, as determined at 15 min of treatment with $100 \mathrm{nM}$ Ang II. Under these conditions, no further increase of receptor number in cell surface was detected, suggesting that a new equilibrium had been reached after 30 min exposure of the cells to Ang II. No increased receptor number was observed in other G-protein-coupled receptors, AT2 or $\beta 2$-adrenoceptors with ARAP1 in transfected HEK-293 cells, indicating that ARAP1 specifically promotes AT1A recycling to the plasma membrane. Immunocytochemical analysis revealed co-localization of recycled Flag epitope-tagged AT1A and GFPtagged ARAP1 in the plasma membrane 45 min after the initial exposure to Ang II (Fig 7). Taken together, these results indicate a role for ARAP1 in recycling of the AT1 receptor to the plasma membrane with presumable concomitant recovery of receptor signal functions.

\section{Conclusion}

In relation to the pathophysiology of essential hypertension, there is no question about pivotal role of the RAS. There is a consensus that the effect of Ang II through its AT1 receptor is manifested in remodeling of the cardiacvascular and renal system. Ten years after cloning of the AT1 receptor, numerous studies have demonstrated that its carboxyl-terminus plays a central role in receptor internalization, desensitization, phosphorylation and recycling. In addition, the carboxyl-terminus of the AT1 receptor directly interacts with numerous proteins, such as heterotrimeric G-proteins, JAK2 kinase, and the recently-identified proteins ATRAP and ARAP1, which initiate receptor activation and signal transduction. Interestingly, ATRAP enhances AT1 receptor internalization as well as receptor desensitization, and inhibits VSMC growth. ARAP1 promotes AT1 receptor recycling to the plasma membrane, but dose not affect AT1 receptor internalization. These findings suggest that both proteins regulate AT1 receptor but via different pathways.

The identification of novel proteins interacting directly with the carboxyl-terminus of the AT1 receptor will increase our knowledge of how the receptor is regulated in intracellular trafficking from different vesicles to recycle back to the plasma membrane. Importantly, they may lead us to understand the crucial and initiative steps of AT1 receptor-mediated signal transduction pathways. Future studies will investigate the physiological importance of these novel AT1 receptor-associated proteins in the cardiovascular system with knock-out and transgenic mice technology.

\section{ACKNOWLEDGEMENTS}

The authors thank Dr. Danny Baranes for the imaging by confocal laser scanning microscopy and Mr. O.M. Da Silva for his critical reading of this manuscript. The work reported here has been supported by grants from the Canadian Institutes of Health Research and the Heart and Stroke Foundation of Canada. Deng-Fu Guo is a scholar from the Heart and Stroke Foundation of Canada.

\section{REFERENCES}

[1] Page IH, Helmer OM. A crystalline pressor substance (angiotonin) resulting from the reaction between renin and renin activator. J Exp Med 1940; 71:29-42.

[2] Braun-Menendez E, Fasciolo E, Leloir JC, Munoz JM. The substance causing renal hypertension. J Physiol (London) 1940; 98:283-98.

[3] Skeggs LT, Marsh WH, Kahn JR, Shumway NP. The purification of hypertensin I. J Exp Med 1954; 100: 363-70.

[4] Lentz KE, Skeggs LT, Maesh WH, Woods KR, Shumway NP. Amino acid composition of hypertensin II and its biochemical relationship to hypertensin I. J Exp Med 1956; 104:183-91.

[5] Skeggs LT, Marsh WH, Kahn JR, Shumway NP. Amino acid composition and electrophoretic properties of hypertensin I. J Exp Med 1955; 102:435-40.

[6] Skeggs LT, Kahn JR, Shumway NP. Preparation and function of hypertensin-converting enzyme. J Exp Med 1956; 103:295-9.

[7] Sasaki K, Yamano Y, Bardhan S, Iwai N, Murray JJ, 
Hasegawa M, Matsuda T, Inagami T. Cloning and expression of a complementary DNA encoding a bovine adrenal angiotensin II type 1 receptor. Nature 1991; 351:230-3.

[8] Murphy TJ, Alexander WR, Griending KK, Runge MS, Bernstein KE. Isolation of a cDNA encoding the vascular type 1 angiotensin II receptor. Nature 1991; 351:253-6.

[9] Iwai N, Yamano Y, Chaki S, Konishi F, Bardhan S,Tibbetts $\mathrm{C}$, Inagami T. Rat angiotensin II receptor: cDNA sequence and regulation of the gene expression. Biochem Biophys Res Commun 1991; 177:299-304.

[10] Iwai N, Inagami T. Identification of two subtypes in the rat type 1 angiotensin II receptor. FEBS Lett 1992; 298: 257-60.

[11] Sandberg K, Ji H, Clark AJI, Shapira H, Catt KJ. Cloning and expression of a novel angiotensin II receptor subtype. J Biol Chem 1992; 267:9455-8.

[12] Kakar SS, Sellers JC, Devor DC, Musgrove LC, Neil JD. Angiotensin II type-a receptor subtype cDNAs: differential tissue expression and hormonal regulation. Biochem Biophys Res Commun 1992; 183:1090-6.

[13] Elton TS, Stephan CC, Taylor GR, Kimball MG, Martin MM, Durand JN, et al. Isolation of two distinct type 1 angiotensin II receptor genes. Biochem Biophys Res Commun 1992; 184:1067-73.

[14] Yoshida H, Kakinuma J, Guo DF, Furuta H, Iwai N, van der Meer-de-Jong R, Inagami T, Ichikawa I. Analysis of the evolution of angiotensin II type 1 receptor gene in mammals (mouse, rat, bovine, and human). Biochem Biophys Res Commun 1992; 186:1042-9.

[15] Sasamura H, Hein L, Krieger JE, Pratt RE, Kobilka BK, Dzau VJ. Cloning, characterization and expression of two angiotensin receptor (AT-1) isoforms from the mouse genome. Biochem Biophys Res Commun 1992; 185:253-9.

[16] Furuta H, Guo DF, Inagami T. Molecular cloning and sequencing of the gene encoding human angiotensin II type 1 receptor. Biochem Biophys Res Commun 1992; 183:8-13.

[17] Takayanagi R, Ohnaka K, Sakai Y, Nakao R, Yanase T, Haji $\mathrm{M}$, et al. Molecular cloning, sequencing analysis and expression of a cDNA encoding human type 1 angiotensin II receptor. Biochem Biophys Res Commun 1992; 183: 910-6.

[18] Bersma DZ, Ellis C, Kumar C, Nuthulaganti P, Kersten $\mathrm{H}$, Elshourbagy N. et al. Cloning and characterization of a human angiotensin II type 1 receptor. Biochem Biophys Res Commun 1992; 183:989-95.

[19] Mauzy CA, Hwang O, Egloff AM, Wu LH, Chung FZ. Cloning, expression and characterization of a gene encoding the human angiotensin II type 1A receptor. Biochem Biophys Res Commun 1992; 186:277-84.

[20] Curnow KM, Pascoe L, White PC. Genetic analysis of the human type 1 angiotensin II receptor. Mol Endocrinol 1992; 6:1113-8.

[21] Szpirer C, Riviere M, Szpirer J, Levan G, Guo DF, Iwai N, Inagami T. Chromosomal assignment of human and rat hypertension candidate genes: type 1 angiotensin II receptor genes and SA gene. J Hypertension 1999; 11:91925.

[22] Lewis JL, Serikawa T, Warnock DG. Chromosomal localization of angiotensin II type 1 receptor isoforms in the rat. Biochem Biophys Res Commun 1993; 194:667-82.

[23] Sandberg K, Ji H, Millan MA, Catt KJ. Amphibian myocardial angiotensin II receptors are distinct from mammalian AT1 and AT2 subtypes. FEBS Lett 1991; 284:281-4.

[24] Ji H, Sandberg K, Zhang Y, Catt KJ. Molecular cloning, sequencing and functional expression of an amphibian angiotensin II receptor. Biochem Biophys Res Commun 1993; 194:756-62.

[25] Burns KD, Inagami T, Harris RC. Cloning of a rabbit kidney cortex AT1 angiotensin II receptor that is present in proximal tubule epithelium. Am J Physiol 1993; 264: F645-54.M

[26] Murphy TJ, Nakamura Y, Takeuchi K, Alexander RW. A cloned angiotensin receptor isoform from the turkey adrenal gland is pharmacologically distinct from mammalian angiotensin receptors. J Pharmacol Exp Ther 1993; 44:1-7.

[27] Chang RSL, Lotti V, Keegan ME. Inactivation of angiotensin II receptors in bovine adrenal cortex by dithiothreitol. Biochem Pharmacol 1982; 31:1903-6.

[28] Takeuchi K, Alexander W, Nakamura Y, Tsujino T, Murphy TJ. Molecular structure and transcriptional function of the rat vascular AT1A angiotensin receptor gene. Circ Res 1993; 73:612-21.

[29] Guo DF, Inagami T. The genomic organization of the rat angiotensin II receptor AT1B. Biochim Biophys Acta 1994; 1218:91-4.

[30] Guo DF, Furuta H, Mizukoshi M, Inagami T. The genomic organization of human angiotensin II type 1 receptor. Biochem Biophys Res Commun 1994; 200:313-9.

[31] Du Y, Yao A, Guo DF, Inagami T, Wang DH. Regulation of angiotensin II receptor in rat kidney by dietary sodium. Hypertension 1995; 25:872-7.

[32] Chen X, Li W, Yoshida H, Tsuchida S, Nishimura H, Takemoto F, Okubo S, Fogo A, Matsusaka T, Ichikawa I. Targeting deletion of angiotensin type $1 \mathrm{~B}$ receptor gene in the mouse. Am J Physiol 1997; 272:F299-304.

[33] Ito M, Oliverio MI, Mannon PJ, Best CF, Maeda N, Smithies O, Coffman TM. Regulation of blood pressure by the type 1A angiotensin II receptor gene. Proc Natl Acad Sci USA 1995; 92:3521-5.

[34] Sugaya T, Nishimura S, Tanimoto K, Takimoto E, Yamagishi T, Imamura K, Goto S, Imaizumi K, Hisada Y, Otsuka A, et al. Angiotensin II type 1a receptor deficient mice with hypotension and hyperreninemia. J Biol Chem1995; 270:18719-22.

[35] Guo DF, Inagami T. Epidermal growth factor enhanced human angiotensin II receptor type 1 . Hypertension 1994; 23:1032-5.

[36] Guo DF, Uno S, Nakamura N, Ishihata H, Inagami T. Identification of cis-acting glucocorticoid responsive elements in rat angiotensin II type 1A promoter. Circ Res 1995; 7:249-57.

[37] Makita N, Iwai N, Inagami T, Madr K. Two distinct pathways in the down-regulation of type 1 angiotensin II receptor gene in rat glomerular mesangial cells. Biochem Biophys Res Commun 1992; 182:1094-9.

[38] Marrero MB, Schieffer B, Paxton WG, Heerdt L, Berk BC, Delafontaine P, Bernstein KE. Direct stimulation of Jak/ 
The angiotensin II type 1 receptor and receptor-associated proteins

STAT pathway by the angiotensin II AT1 receptor. Nature 1995; 375:247-50.

[39] Li X, Earp HS. Paxillin is tyrosine phosphorylated by and preferentially associated with the calcium-dependent tyrosine kinase in rat liver epithelial cells. J Biol Chem 1997; 272:14341-8.

[40] Sadoshima J, Izumo S. The heterotrimeric Gq proteincoupled angiotensin II receptor activates p21ras via the tyrosine kinase-Shc-Grb2-Sos pathway in cardiac myocytes. EMBO J 1996; 15:775-87.

[41] Marrero MB, Scheiffer B, Paxton WG, Scheiffer E, Bernstein KE. Electroporation of pp60c-src antibodies inhibits the angiotensin II activation of phospholipase C-g1 in rat aortic muscle cells. J Biol Chem 1995; 270:15734-8.

[42] Linseman DA, Benjamin CW, Jones CA. Convergence of angiotensin II and platelet-derived growth factor receptor signaling cascades in vascular smooth muscle cells. $J$ Biol Chem 1995; 270:12563-8.

[43] Du J, Sperling LS, Marrero MB, Philips L, Delafontaine P. G-protein and tyrosine kinase receptor cross-talk in rat aortic smooth muscle cells: thrombin and angiotensin II induced tyrosine phosphorylation of insulin receptor substrate-1 and insulin-like growth factor 1 receptor. Biochem Biophys Res Commun 1996; 218:934-9.

[44] Eguchi S, Numaguchi K, Iwasaki H, Matsumoto T, Yamakawa T, Utsunomiya H, Motley ED, Kawakastu H, Owada KM, Hirata Y, Marumo F, Inagami T. Calciumdependent epidermal growth factor receptor transactivation mediates the angiotensin II-induced mitogen-activated protein kinase activation in vascular smooth muscle cells. J Biol Chem 1998; 273:8890-6.

[45] Li X, Lee JW, Graves LM, Earp HS. Angiotensin II stimulates ERK via two pathways in epithelial cells: protein kinase $\mathrm{C}$ suppresses a $\mathrm{G}$ protein coupled receptorEGF receptor transactivation pathway. EMBO J 1998; 17:2574-83.

[46] Murasawa S, Mori Y, Nozawa Y, Gotoh N, Shibuya M, Masaki H, Maruyama K, Tsutsumi Y, Moriguchi Y, Shibazaki Y, Tanaka Y, Iwasaka T, Inada M, Matsubara $\mathrm{H}$. Angiotensin II type 1 receptor-induced extracellular signal-regulated protein kinase activation is mediated by $\mathrm{Ca}^{2+} /$ calmodulin-dependent transactivation of epidermal growth factor receptor. Circ Res 1998; 82:1338-48.

[47] Bhat GJ, Thekkumkara TJ, Thomas WG, Conrad KM, Baker KM. Angiotensin II stimulates sis-inducing factorlike DNA binding activity. Evidence that the AT1A receptor activates transcription factor-STAT91 and/or a related protein. J Biol Chem 1994; 269:31443-9.

[49] Leduc L, Meloche S. Angiotensin II stimulates tyrosine phosphorylation of the focal adhesion-associated protein paxillin in aortic smooth muscle cells. J Biol Chem 1995; 270:4401-4.

[50] Schorb W, Peeler TC, Madign NN, Conrad KM, Maker KM. Angiotensin II-induced protein tyrosine phosphorylation in neonatal rat cardiac fibroblasts. J Biol Chem 1994; 269: 19626-32.

[51] Ali MS, Schieffer B, Delafontaine P, Bernstein KE, Ling $\mathrm{BE}$, Marrero MB. Angiotensin II stimulates tyrosine phosphorylation and activation of insulin receptor substrate 1 and protein tyrosine phosphatase $1 \mathrm{D}$ in vascular smooth muscle cells. J Biol Chem 1997; 272:12373-9.

[52] Morrero MB, Paxton WG, Duff JL, Berk BC, Berstein KE. Angiotensin II stimulates tyrosine phosphorylation of phospholipase C-g1 in vascular smooth muscle cells. J Biol Chem 1994; 269:10935-9.

[53] Sayeski PP, Ali MS, Harp JB, Marrero MB, Berstein KE. Phosphorylation of p130CAS by angiotensin II is dependent on c-Src, intracellular $\mathrm{Ca}^{2+}$, and protein kinase C. Circ Res 1998; 82:1279-88.

[54] Tang H, Guo DF, Porter JP, Wanaka Y, Inagami T. Role of cytoplasmic tail of the type 1 angiotensin II receptor in agonist- and phorbol ester-induced desensitization. Circ Res 1998; 82:523-31.

[55] Leszcynski D, Joenvarra S, Foegh ML. Protein kinase Cregulates proliferation but not apoptosis in rat coronary vascular smooth muscle cells. Life Sci 1996; 58:599-60. [56] Taubman MB, Berk BC, Izumo S, Tsuda T, Alexander RW, Nadal-Ginard B. Angiotensin II induces c-fos mRNA in aortic smooth muscle. J Biol Chem 1989; 264:526-30.

[57] Ohyama K, Yamano Y, Chaki S, Kondo T, Inagami T. Domains for $\mathrm{G}$ protein coupling in angiotensin II receptor 1: studies by site-directed mutagenesis. Biochem Biophys Res Commun 1992; 189:677-83.

[58] Sano T, Ohyama K, Yamano Y, Nakagomi Y, Nakazawa S, Kikyo M, Shirai H, Blank JS, Exton JH, Inagami T. A domain for $\mathrm{G}$ protein coupling in carboxyl-terminal tail of rat angiotensin II receptor. J Biol Chem 1997; 272: 23631-6.

[59] Ali MS, Sayeski PP, Dirksen LB, Hayzer DJ, Marrero MB, Bernstein KE. Dependence on the motif YIPP for the physical association of JAK2 kinase with the intracellular carboxyl tail of the angiotensin II AT1 receptor. J Biol Chem 1997; 272:13382-8.

[60] Oppermann M, Freedman NJ, Alexander RW, Lefkowitz RJ. Phosphorylation of the type 1A angiotensin II receptor by $\mathrm{G}$ protein-coupled receptor kinases and protein kinase C. J Biol Chem 1996; 271:13266-72.

[61] Venema RC, Ju H, Venema VJ, Schieffer B, Harp JB, Ling BN, Eaton DC, Marrero MB. Angiotensin II-induced association of phospholipase C-g1 with the G-protein coupled AT1 receptor. J Biol Chem 1998; 273:7703-8.

[62] Thomas WG, Motel TJ, Kule CE, Karoor V, Baker KM. Phosphorylation of the angiotensin II (AT1A) receptor carboxyl-terminus: a role in receptor endocytosis. Mol Endocrinol 1998; 12:1513-24.

[63] Noda K, Feng YH, Liu XP, Saad Y, Husain A, Karnik SS. The active state of the AT1 angiotensin receptor is generated by angiotensin II induction. Biochemistry 1996; 35:16435-42.

[64] Hjorth SA, Schambye HT, Greenlee WJ, Schwartz TW. Identification of peptide binding residues in the extracellular domains of the AT1 receptor. J Biol Chem 1994; 269:30953-9.

[65] Schambye HT, Hjorth SA, Bergsma DJ, Sathe G, Schwartz TW. Differentiation between binding sites for angiotensin II and nonpeptide angagonists on the angiotensin II type 1 receptors. Proc Natl Acad Sci USA 1994; 91 : 7046-50.

[66] Noda K, Saad Y, Karnik SS. Interaction of Phe8 of angiotensin II with Lys199 and His256 of AT1 receptor in 
agonist activation. J Biol Chem 1995; 270:28511-4.

[67] Monnot C, Bihoreau C, Conchon S, Curnow KM, Corvol P, Clauser E. Polar residues in the transmembrane domains of type 1 angiotensin II receptor are required for binding and coupling. Reconstitution of the binding site by coexpression of two deficient mutants. J Biol Chem 1996; 271:1507-13.

[68] Hunyady L, Balla T, Catt KJ. The ligand binding site of the angiotensin AT1 receptor. Trends Pharmacol Sci 1996; 17:135-40.

[69] Inoue Y, Nakamura N, Inagami T. A review of mutagenesis studies of angiotensin II type 1 receptor, the threedimensional receptor model in search of the agonist and antagonist binding site and the hypothesis of a receptor activation mechanism. J Hypertension 1997; 15:703-14.

[70] Karnik SS, Husain A, Graham RM. Molecular determinants of peptide and non-peptide binding to the AT1 receptor. Clin Exp Pharmacol Physiol Suppl 1996; 3:S5866.

[71] Han HM, Shimuta SI, Kanashiro CA, Oliveira L, Han SW, Paiva AC. Residues Val254, His256, and Phe259 of the angiotensin II AT1 receptor are not involved in ligand binding but participate in signal transduction. Mol Endocrinol 1998; 12:810-4.

[72] Balmforth AJ, Lee AJ, Warburton P, Donnelly D, Ball SG. The conformational change responsible for AT1 receptor activation is dependent upon two juxtaposed asparagine residues on transmembrane helices III and VII. J Biol Chem 1997; 272:4245-51.

[73] Groblewski T, Maigret B, Larguier R, Lombard C, Bonnafous JC, Marie J. Mutation of Asn111 in the third transmembrane domain of the AT1A angiotensin II receptor induces its constitutive activation. J Biol Chem 1997; 272:1822-6.

[74] Marie J, Maigret B, Joseph MP, Larguier R, Nouet S, Lombard C, Bonnafous JC. Tyr292 in the seventh transmembrane domain of the AT1A angiotensin II receptor is essential for coupling to phospholipase C. J Biol Chem 1994; 269:20815-8.

[75] Hunyady L, Ji H, Jagadeesh G, Zhang M, Gaborik Z, Mihalik B, Catt KJ. Dependence of AT1 receptor function on adjacent asparagine residues in the seventh transmembrane helix. Mol Pharmacol 1998; 54:427-34.

[76] Yamano Y, Ohyama K, Kikyo M, Sano T, Nakagomi Y, Inoue Y, Nakamura N, Morishima I, Guo DF, Hamakubo $\mathrm{T}$, Inagami T. Mutagenesis and the molecular modeling of the rat angiotensin II receptor (AT1). J Biol Chem 1995; 270:14024-30.

[77] Sorkin A, Waters CM. Endocytosis of growth factor receptors. BioEssays 1993; 15:375-82.

[78] Morris SA, Ahle S, Ungewickell E. Clathrin-coated vesicles. Curr Opinion Cell Biol 1989; 1:684-90.

? [79] Sorkin A, Carpenter G. Interaction of activated EGF receptors with coated pit adaptins. Science 1996; 261: 612-5.

[80] Hunyady L, Bor M, Balla T, Catt KJ. Identification of a cytoplasmic Ser-Thr-Leu motif that determines agonistinduced internalization of the AT1 angiotensin receptor. J Biol Chem 1994; 269:31378-82.

[81] Thomas WG, Thekkumkara TJ, Motel TJ, Baker KM.
Stable expression of a truncated AT1A receptor in CHOK1 cells. The carboxyl-terminal region directs agonistinduced internalization, but not receptor signaling or desensitization. J Biol Chem 1995; 270:207-13. [82] Thomas WG, Baker KM, Motel TJ, Thekkumkara TJ. Angiotensin II receptor endocytosis involves two distinct regions of the cytoplasmic tail. A role for residues on the hydrophobic face of a putative amphipathic helix. J Biol Chem 1995; 270:22153-9.,p> [83] Balmforth AJ, Lee AJ, Bajaj BP, Dickinson CJ, Warburton P, Ball SG. Functional domains of the C-terminus of the rat angiotensin AT1A receptor. Eur J Pharmacol 1995; 291:135-41.

[84] Gaborik Z, Mihalik B, Jayadev S, Jagadeesh G, Catt KJ, Hunyady L. Requirement of membrane-proximal amino acids in the carboxyl-terminal tail for expression of the rat AT1a angiotensin receptor. FEBS Lett 1998; 428: 147-51.

[85] Hunyady L, Bor M, Baukal AJ, Balla T, Catt KJ. A conserved NPLFY sequence contributes to agonist binding and signal transduction but is not an internalization signal for the type 1 angiotensin II receptor. J Biol Chem 1995; 270:16602-9.

[86] Hall RA, Richard TP, Lefkowitz RJ. Heptahelical receptor signaling: beyond the G protein paradigm. J Cell Biol 1999; 145:927-32.

[87] Benovic JL, Bouvier M, Caron MG, Lefkowitz RJ. Regulation of adenylyl cyclase-coupled beta- adrenergic receptors. Annu Rev Cell Biol 1988; 4:405-28.

[88] Dohlman HG, Thorner J, Caron MG, Lefkowitz RJ. Model systems for the study of seven- transmembrane-segment receptors. Annu Rev Biochem 1991; 60:653-88.

[89] Ferguson SS, Barak LS, Zhang J, Caron MG. G-proteincoupled receptor regulation: role of G-protein-coupled kinases and arrestins. Can J Physiol Pharmacol 1996; 74: 1095-110.

[90] Ferguson SS, Downey WE, Colapietro AM, Barak LS, Menard L, Caron MG. Role of beta- arrestin in mediating agonist-promoted G protein-coupled receptor internalization. Science 1996; 271:363-6.

[91] Diviani D, Lattion AL, Larbi N, Kunapuli P, Pronin A, Benovic JL, Cotecchia S. Effect of different G proteincoupled receptor kinases on phosphorylation and desensitization of the aB-adrenergic receptor. J Biol Chem 1996; 271:5049-58.

[92] Yu S, Lefkowitz RJ, Hausdorff WP. Beta-adrenergic receptor sequestration. A potential mechanism of receptor resensitization. J Biol Chem 1993; 268:337-41.

[93] Conchon S, Peltier N, Covol P, Clauser E. A noninternalized nondesensitized truncated AT1A receptor transduces an amplified Ang II signal. Am J Physiol 1998; 274:E33645.

[94] Feng X, Zhang J, Barak LS, Meyer T, Caron MG, Hannun YA. Visualization of dynamic trafficking of a protein kinase $\mathrm{C} /$ green fluorescence protein conjugate reveals differences in $\mathrm{G}$ protein-coupled receptor activation and desensitization. J Biol Chem 1998; 273:10775-62.

[95] Hebert TE, Loisel TP, Adam L, Ethier N, Onge SS, Bouvier M. Functional rescue of a constitutively desensitized b2AR through receptor dimerization. Biochem J 1998; 330:287-93. 
[96] Maggio R, Barbier P, Fornai F, Corsini GU. Functional role of the third cytoplasmic loop in muscarinic receptor dimerization. J Biol Chem 1996; 271:1055-60.

[97] Ng GY, Oí Dowd BF, Lee SP, Chung HT, Brann MR, Seeman P, George SR. Dopamine D2 receptor dimers and receptor-blocking peptides. Biochem Biophys Res Commun 1996; 277:200-4.

[98] Nimchinsky EA, Hof PR, Janssen WGM, Morrison JH, Schmauss C. Expression of dopamine D3 receptor dimmers and tetramers in brain and in transfected cells. J Biol Chem 1997; 272:29229-37.

[99] Romano C, Yang WL, Oí Malley KL. Metabotropic glutamate receptor 5 is a disulfide- linked dimer. J Biol Chem 1996; 271:28612-6.

[100] Cvejic S, Devil LA. Dimerization of the d-opioid receptor: implication for a role in receptor internalization. J Biol Chem 1997; 272:26959-64.

[101] Balmforth AJ, Shepherd FH, Warburton P, Ball SG. Evidence of an important and direct role for protein kinase $\mathrm{C}$ in agonist-induced phosphorylation leading to desensitization of the angiotensin AT1A receptor. Br J Pharmacol 1997; 122:1469-77.

[102] Smith RD, Baukal AJ, Zolyomi A, Gaborik Z, Hunyady L, Sun L, Zhang M, Chen HC, Catt KJ. Agonist-induced phosphorylation of the endogenous AT1 angiotensin receptor in bovine adrenal glomerulosa cells. Mol Endocrinol 1998; 12:634-44.

[103] Paxton WG, Marrero MB, Klein JD, Delafontaine P, Berk $\mathrm{BC}$, Bernstein KE. The angiotensin II AT1 receptor is tyrosine and serine phosphorylated and can serve as a substrate for the src family of tyrosine kinases. Biochem Biophys Res Commun 1994; 200:260-7.
[104] Kai H, Lu D, Raizada MK. Angiotensin II-induced phosphorylation of the vascular type 1 angiotensin II receptor. Hypertension 1997; 30:351-7.

[105] Yang H, Lu D, Raizada MK. Angiotensin II-induced phosphorylation of the AT1 receptor from rat brain neurons. Hypertension 1997; 30:351-7.

[106] Hein L, Meinel L, Pratt RE, Dzau VJ, Kobilka BK. Intracellular trafficking of angiotensin II and its AT1 and AT2 receptors: evidence for selective sorting of receptor and ligand. 1997; 11:1266-77.

[107] Daviet L, Lehtonen JYA, Tamura K, Griese DP, Horiuchi M, Dzau VJ. Cloning and characterization of ATRAP, a novel protein that interacts with the angiotensin II type 1 receptor. J Biol Chem 1999; 274:17058-62.

[108] Cui T, Nakagami H, Iwai M, Takeda Y, Shiuchi T, Tamura K, Daviet L, Horiuchi M. ATRAP, novel AT1 receptor associated protein, enhances internalization of AT1 receptor and inhibits vascular smooth muscle cell growth. Biochem Biophys Res Commun 2000; 279: 938-41.

[109] Becherer KA, Rieder SE, Emr SD, Jones EW. Novel syntaxin homologue,Pep12p, required for sorting of lumenal hydrolase to the lysosome-like vacuole in yeast. Mol Biol Cell 1996; 7:579-94.

[110] Darsow T, Burd CG, Emr SD. Acidic di-leucine motif essential for AP3-dependent sorting and restriction of the functional specificity of the Vam3p vacuolar tSNARE. J Cell Biol 1998; 142:913-22. 